\title{
sciendo
}

\section{COMPARISON OF THE COMPOSITION AND QUALITY PROPERTIES OF FROMAGE FRAIS-TYPE CHEESE MANUFACTURED FROM THE MILK OF SELECTED COW BREEDS*}

\author{
Jacek Domagała ${ }^{1}$, Agnieszka Pluta-Kubica $^{1 \star}$, Marek Sady ${ }^{1}$, Genowefa Bonczar $^{1}$, Iwona Duda ${ }^{1}$, \\ Henryk Pustkowiak ${ }^{2}$
${ }^{1}$ Department of Animal Products Technology, University of Agriculture in Krakow, Balicka 122, 30-149 Kraków, Poland
${ }^{2}$ Department of Cattle Breeding, University of Agriculture in Krakow, al. Mickiewicza 24/28, 30-059 Kraków, Poland
•Corresponding author: agnieszka.pluta-kubica@urk.edu.pl

\begin{abstract}
The purpose of this research was to compare the physicochemical and sensorial properties of fromage frais-type cheese produced from milk of different cow breeds. There is no information on this topic in literature. The cheeses were manufactured in laboratory conditions during summer in three independent series from milk of the Polish Holstein-Friesian Black-and-White (HO), Polish Holstein-Friesian Red-and-White (RW) and Polish Red (RP) cows. The milk, whey and cheeses were analysed for chemical composition and physicochemical properties. Moreover, sensory analysis, TPA, protein fractions by SDS PAGE and fatty acid profile by GC were determined in cheeses. A one-way ANOVA was employed and the significance of differences between the means was established using the Duncan's test. The cheeses were found to have a similar acidity and basic chemical composition ( $\mathrm{P} \geq \mathbf{0 . 0 5}$ ), with the exception of fat in dry matter concentration, which was greater in RW than $\mathrm{HO}$ cheese $(\mathrm{P}<0.05)$. The sensory evaluation of fromage frais-type cheeses revealed that they differed only in smell which gained a better score in $\mathrm{RP}$ than $\mathrm{HO}$ cheese $(\mathrm{P}<0.05)$. However, texture analysis showed a significant difference in the hardness and chewiness between cheeses which were the greatest in $\mathrm{HO}$ cheese $(\mathrm{P}<0.05)$. The $\mathrm{RW}$ cheeses were characterised by a greater proportion of whey proteins, trans-vaccenic acid, cis-9, trans-11-linoleic acid and monounsaturated fatty acids $(\mathrm{P}<\mathbf{0 . 0 5})$ than the $\mathrm{HO}$ ones. The cheeses from the RP milk gave the greatest yield. In conclusion, the most beneficial raw material for fromage frais-type cheese manufacture is the RW milk.
\end{abstract}

Key words: dairy cow breeds, fromage frais-type cheese, fatty acid profile, protein fractions, sensory properties

\footnotetext{
*Work financed from statutory activity, DS-3705/KPPZ/2017.
} 
Fromage frais belongs to acid-rennet unripened soft cheeses intended for direct consumption. It can also be called cream cheese as it is soft, unripened, with spreadable and smooth texture without holes and rindless. Its colour ranges from white to light yellow (CODEX STAN 275-1973). It can be produced with or without different herbs and spices such as chives, pepper, paprika, garlic, etc. This type of cheese is very popular in Poland as well as in other European countries.

Currently, there are 12 breeds used for milk production in Poland, including four native breeds (Barłowska et al., 2014). According to the report of the Polish Federation of Cattle Breeders and Dairy Farmers in 2018, the Polish Holstein-Friesian breed of black-and-white type (HO) is the largest livestock population in Poland $(85.00 \%)$, while the red-and-white type (RW) is second $(3.80 \%)$. The Polish Red cattle breed (RP) is one of native breeds in Poland and its population accounts for $0.35 \%$ of the livestock (http://pfhb.pl/fileadmin/user_upload/OCENA/publikacje/ publikacje_2019/RO_Parzniew-wyniki_oceny_za_rok_2018.pdf). This breed used to be present throughout the country and in the mid-1950s it still made up about $20 \%$ of the whole stock (Adamczyk and Szarek, 2009). The intensification of animal production using the selection method led to the creation of high-production breeds. They began to displace the local breeds in the second half of the 20th century (Litwińczuk et al., 2015). In 2018 the average milk yield in HO, RW and RP was 8519,7679 and $3658 \mathrm{~kg}$, respectively (http://pfhb.pl/fileadmin/user_upload/OCENA/publikacje/publikacje_2019/RO_Parzniew-wyniki_oceny_za_rok_2018.pdf). Since 1999 the RP cattle breed has been included in the genetic resources conservation programme (Adamczyk and Szarek, 2009) and most cattle of this breed is raised in mountain areas. Milk of this cow breed, due to a large content of total solids, especially casein, is particularly suitable for cheese production (Litwińczuk et al., 2015).

Cow breed is one of the basic factors influencing the composition and the properties of milk. The composition and the properties of dairy products as well as the efficiency of production depend on the composition of milk as a raw material. The profile of fatty acids in cheese is strongly affected by their composition in the milk, whereas the cheese-making technology has a relatively low influence (De Marchi et al., 2008). According to Litwińczuk et al. (2012), milk from RP cows kept under traditional conditions is characterised by a greater proportion of CLA and polyunsaturated fatty acids than milk from Polish Holstein-Friesian cows maintained in the intensive system. According to Król et al. (2015), milk from cows of local breeds kept in the low-input system contains more CLA, mono- (MUFA) and polyunsaturated fatty acids (PUFA) than the milk of HO maintained in the intensive system, especially during spring-summer production season. Moreover, RP cows from low-input farms with traditional feeding give milk with greater proportion of MUFA, PUFA and CLA than $\mathrm{HO}$ raised in the intensive farming system, regardless of the phase of lactation (Litwińczuk et al., 2016). Vaccenic acid (cis- or trans-11-octadecenoic acid) which belongs to MUFA, as well as cis-9,trans-11 and trans-10,cis-12-linoleic acid (isomers of CLA) have beneficial health effects. The first one has anticancerogenic properties, whereas the second one prevents illnesses such as atherosclerosis, diabetes, neurodegenerative diseases, and cancer. CLA also exhibits anti-obesity effect and enhances the immune system (Domagała et al., 2013). 
In literature, there are only a few studies about the influence of the composition and the properties of milk of different cow breeds on qualitative properties of cheeses. Auldist et al. (2004) found no significant influence of cow breed (Jersey and Friesian) on cheese yield and composition of Cheddar cheese, in spite of the ash content and $\mathrm{pH}$, which were greater in the cheese made from milk of the Jersey breed. De Marchi et al. (2008) investigated the influence of cow breed (Holstein Friesian and Brown Swiss) on the quality of Casolet, Vezzena and Grana Trentino cheeses. They concluded that breed affected fatty acid composition and colour of all examined cheeses but not their hardness. It had a significant influence on the basic chemical composition only in the case of Vezzena cheese. Hurtaud et al. (2009) stated that cow breed (Holstein and Normande) affected the protein content, colour, texture and taste of Camembert. However, there is no information on this topic regarding fromage frais-type cheeses.

In relation to this, the objective of the presented work was to compare the physicochemical and sensorial properties of fromage frais-type cheese produced from milk of different cow breeds. HO and RW were chosen as the first and second largest livestock population in Poland, whereas RP as a native breed.

\section{Material and methods}

\section{Milk for cheese manufacture}

The raw milk came from two types of the Polish Holstein-Friesian breed: Blackand-White (HO) and Red-and-White (RW) as well as Polish Red breed (RP), bred in Podhale region (southern Poland), each on a different farm. The bulk milk was taken separately from each source during summer from morning milking of that day and the evening milking of the previous day mixed together, in three independent series. Milk from all cows of a certain breed or type in the herd of 20-30 cows was mixed, so the milk came from cows that were in different periods of lactation, at different ages. In this period, the HO and RW cows were fed with haylage, grass forage and supplementary mixtures, while the RP cows were fed on pastures, with hay and also with supplementary mixtures. Irrespectively of breed or type, supplementary mixtures consisted of 2-4 kg/day of ground mixed cereal middling (14-21\% of protein) with minerals and vitamins. Grass forage and pastures had similar chemical composition and nutritional value. The cows in each herd were fed at will and received a complete diet. Average milk yield of HO, RW and RP cows was 5500, 5500 and $3500 \mathrm{~kg}$, respectively. The milk was cooled immediately after milking and transported in refrigerated conditions directly to the laboratory of the Department of Animal Products Technology where it was analysed and processed. The raw milk was standardised to the fat content of $2.6 \%$ in order to produce cheese with approximately $45 \%$ of fat in dry matter. Then it was analysed for basic composition, physicochemical properties and intended to production of fromage frais-type cheese. 


\section{Production of cheese}

Fromage frais-type cheeses were prepared three times (on 3 different days) for each source of milk (HO, RW, RP), according to the diagram presented in Figure 1. Each time, 151 of vat milk standardised to fat content, mesophilic culture FD-DVS CHN-19 (Chr. Hansen, Denmark) and Fromase 2200TL (DSM, Netherlands) were used. From $15 \mathrm{l}$ of vat milk, $2.5-2.8 \mathrm{~kg}$ of cheese were obtained.

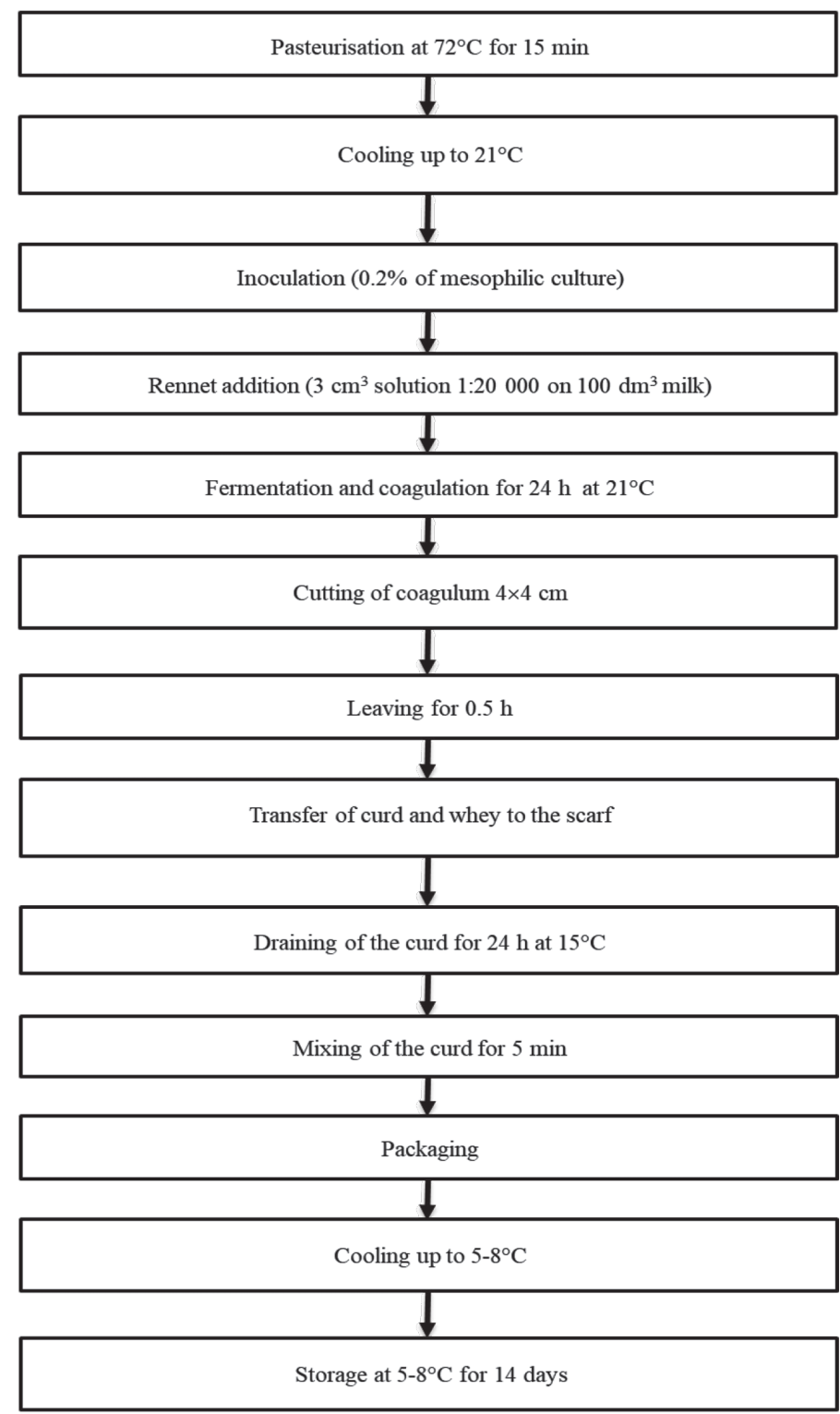

Figure 1. Diagram of the fromage frais-type cheese production 
The curd after mixing was packed into plastic boxes with a capacity of $200 \mathrm{~cm}^{3}$. The produced cheeses were stored for $24 \mathrm{~h}$ in refrigerated conditions and then analysed. The composition and the properties of whey obtained after cheese production were also determined. The yield of cheese production was calculated. The curd after mixing was weighed and the mass of cheese that would be produced from 1001 of milk was calculated.

\section{Analysis of milk and whey}

The analysis of milk and whey was performed in triplicate. The volume of every sample was approximately $100 \mathrm{~cm}^{3}$. The content of solids, total protein, fat and lactose was conducted automatically using an analysis calibrated for milk and whey (MilkoScan, Foss, Denmark) in Małopolska Centre of Food Monitoring at the Faculty of Food Technology, while the acidity and $\mathrm{pH}$ were determined according to AOAC (2007). Additionally, the content of ash and milk density were determined according to AOAC (2007).

\section{Chemical composition and acidity of cheese}

The content of water, total protein, fat in dry matter as well as acidity and $\mathrm{pH}$ were analysed in triplicate according to AOAC (2007) and ISO 3433:2008.

\section{Sensory evaluation of cheese}

The sensory evaluation of fromage frais-type cheese was done in a sensory laboratory equipped with six individual boxes by a trained panel consisting of six persons whose sensory sensitivity was proven. The panellists were tested for ageusia and anosmia and taste and smell detection thresholds. They were instructed about the process of evaluating the different sensory attributes and familiar with descriptive terms used.

The sensory evaluation was performed using two methods: a 5-point scale and a triangle test. A 5-point scale was from 1 - the worst, to 5 - the best). The following quality properties were evaluated: colour, appearance, consistency, taste and smell. The proper indices of importance were established according to Baryłko-Pikielna and Matuszewska (2009) and ascribed to colour, appearance, consistency, taste and smell, as follows: $0.10,0.15,0.25,0.35$ and 0.15 , respectively. The study of the parameters allowed calculation of the overall quality (the sum of the scores of the properties multiplied by the corresponding indices). In order to establish the essential difference existing in sensory quality between cheeses from milk of the $\mathrm{HO}$ and RW as well as the $\mathrm{HO}$ and RP cows the triangle test was performed. Every panellist received 2 sets of comparisons regarding $\mathrm{HO}$ and RW and 2 sets of comparisons regarding $\mathrm{HO}$ and RP. Six combinations were created in total (AAB, ABA, BAA, BBA, BAB, $\mathrm{ABB})$. All comparisons were made in one session for every series of research. For every comparison 12 opinions were obtained. For this number of opinions the minimal number of correct answers (identifying the odd sample) necessary to establish the significance of differences between compared cheeses was 8 at $\mathrm{P}<0.05$ and 9 at $\mathrm{P}<0.01$ (Baryłko-Pikielna and Matuszewska, 2009). 


\section{Texture profile analysis of cheese}

Instrumental texture profile analysis (TPA) was carried out in triplicate using Universal Texture Analyser TA-XTPlus (Stable Micro Systems, Surrey, UK) controlled by a computer. The temperature of the cheese samples was $10 \pm 2^{\circ} \mathrm{C}$. As a tool for the evaluation of textural properties, the penetrometric test was performed using a SMS P/20 probe of cylindrical shape and of $20 \mathrm{~mm}$ in diameter and $40 \mathrm{~mm}$ in height. The depth of penetration was $25 \mathrm{~mm}$ with a penetration rate of $1 \mathrm{~mm} / \mathrm{s}$. As a result, diagrams of force dependence on time were plotted and thereafter analysed using the computer program Texture Expert for Windows v. 1.05 (Stable Micro Systems, Surrey, UK). The Fracture TPA algorithm was applied, which allowed the assignment of hardness, adhesiveness, springiness, cohesiveness, chewiness and resilience of cheeses (Manual of the TA-XTPlus).

\section{Analysis of protein fraction of cheese}

The distribution of protein fractions was conducted in six replicates using the electrophoretic method SDS PAGE on polyacrylamide gel (Laemmli, 1970). Two g of cheese were homogenised with $10 \mathrm{~cm}^{3}$ of extraction buffer. The extraction buffer contained $0.5 \mathrm{M}$ Tris- $\mathrm{HCl}$ ( $\mathrm{pH} 6.8$ ), glycerol, 10\% SDS and deionised water in ratio of $1.25: 2.5: 2: 3.55$. Then $0.95 \mathrm{~cm}^{3}$ of reducing buffer, which contained $0.5 \mathrm{M}$ Tris- $\mathrm{HCl}$ (pH 6.8), glycerol, 10\% SDS, $0.5 \%$ bromophenol blue and deionised water in ratio of $1.25: 2.5: 2: 0.2: 3.55$, was mixed with $0.05 \mathrm{~cm}^{3}$ of $\beta$-mercaptoethanol. Next, $0.02 \mathrm{~cm}^{3}$ of this mixture was added to $0.01 \mathrm{~cm}^{3}$ of sample extract and incubated at $95^{\circ} \mathrm{C}$ for $4 \mathrm{~min}$. Separating gel contained: $0.05 \mathrm{~cm}^{3}$ of $10 \%$ ammonium persulfate (APS), $0.005 \mathrm{~cm}^{3}$ of TEMED, $2.4 \mathrm{~cm}^{3}$ of distilled water, $5 \mathrm{~cm}^{3}$ of $30 \%$ Acrylamide/ Bis-acrylamide, $2.5 \mathrm{~cm}^{3}$ of $1.5 \mathrm{M}$ Tris- $\mathrm{HCl}(\mathrm{pH} 8.80), 0.1 \mathrm{~cm}^{3}$ of $10 \%$ SDS. Stacking gel contained: $0.05 \mathrm{~cm}^{3}$ of $10 \%$ APS, $0.005 \mathrm{~cm}^{3}$ of TEMED, $6.1 \mathrm{~cm}^{3}$ of distilled water, $1.3 \mathrm{~cm}^{3}$ of $30 \%$ Acrylamide/Bis-acrylamide, $2.5 \mathrm{~cm}^{3}$ of $0.5 \mathrm{M}$ Tris- $\mathrm{HCl}(\mathrm{pH}$ $6.80), 0.1 \mathrm{~cm}^{3}$ of $10 \%$ SDS. $25 \mathrm{mM}$ Tris, $192 \mathrm{mM}$ glycine, $0.1 \%$ SDS running buffer was used. All reagents listed were obtained from BIORAD (USA). The separation was carried out at a voltage of $100 \mathrm{~V}$ with the Mini Protean 3 Cell (BIORAD, USA). Two $\mathrm{dm}^{3}$ of colouring solution was prepared as follows: $0.7 \mathrm{~g}$ of $0.025 \%$ Coomassie Blue R-250 (BIORAD, USA), $800 \mathrm{~cm}^{3}$ of $40 \%$ methanol (POCH S.A., Poland) and $140 \mathrm{~cm}^{3}$ of $7 \%$ acetic acid (POCH S.A., Poland) were dissolved in deionised water. One $\mathrm{dm}^{3}$ of de-colouring buffer was prepared as follows: $400 \mathrm{~cm}^{3}$ of $40 \%$ methanol and $70 \mathrm{~cm}^{3}$ of $7 \%$ acetic acid were dissolved in deionised water. Standards of milk proteins were obtained from Sigma-Aldrich (Poland). Quantitative analysis of the obtained gels was performed using a computer programme Gelscan 2.0 from Kucharczyk, Poland.

\section{Determination of fatty acids composition in cheese}

The extraction of total lipids was performed in triplicate according to the Folch et al. (1957) method, while the esterification and determination of total fatty acids composition were performed according to the de Man (1964) method, with modifications. Two $\mathrm{g}$ of cheese sample was homogenised with $34 \mathrm{~cm}^{3}$ of chloroform : methanol mixture (2:1, v/v) (POCH S.A., Poland) at $5000 \mathrm{rpm}$ for $10 \mathrm{~min}$ using 
MPW-120 (Mechanika Precyzyjna, Poland). It was left for $5 \mathrm{~min}$ and homogenised again at $1000 \mathrm{rpm}$ for $5 \mathrm{~min}$. Then the mixture was transferred quantitatively to a regular cylinder and made up with the extraction mixture to $40 \mathrm{~cm}^{3}$. Next, it was filtered through a filter paper and its volume was measured. Then $0.58 \% \mathrm{NaCl}(\mathrm{POCH}$ S.A., Poland) solution was added in the amount of $20 \%$ of the filtrate volume. After shaking and separation of the phases, the alcohol-water phase was removed, and the chloroform phase was washed 3 times using $1-2 \mathrm{~cm}^{3}$ of the mixture of the solutions (chloroform : methanol : $0.58 \% \mathrm{NaCl}, 3: 48: 47, \mathrm{v} / \mathrm{v}$ ). Next, the chloroform phase was recovered. It contained approximately $0.05 \mathrm{~g}$ of fat in $1 \mathrm{~cm}^{3} .0 .5 \mathrm{~cm}^{3}$ of $0.025 \mathrm{M}$ methanolic solution of sodium methylate (POCH S.A., Poland) was added to $0.1 \mathrm{~cm}^{3}$ of the extracted fat. Then the mixture was heated at $60^{\circ} \mathrm{C}$ until it became clear. The fatty acids analysis was performed using a Trace GC Ultra gas chromatograph (Thermo Electron Corp., USA) equipped with a Supelcowax 10 column $(30 \mathrm{~m} \times 0.25 \mathrm{~mm} \times 0.23 \mu \mathrm{m})$. As gaseous phase helium 5.0 (Linde Gaz Polska Sp. $\mathrm{z}$ o.o., Poland) was applied with the flow rate of $5 \mathrm{~cm}^{3} / \mathrm{min}$. The feeder and the detector had the temperature of 220 and $250^{\circ} \mathrm{C}$, respectively. The temperature of the column was kept at $60^{\circ} \mathrm{C}$ for $3 \mathrm{~min}$, then was raised at a rate of $7^{\circ} \mathrm{C} / \mathrm{min}$ up to $200^{\circ} \mathrm{C}$ and was held at this temperature for $20 \mathrm{~min}$. The obtained peaks on chromatograms were compared with an internal standard and the percentages of particular fatty acids were calculated based on their areas. The results were expressed in $\%$ of total peaks area.

\section{Statistical analysis}

The obtained results were statistically analysed using Statistica version 12 (StatSoft Inc., USA). Means and standard deviations were calculated. A one-way ANOVA was employed and the significance of differences between the means was established using the Duncan's test.

\section{Results}

\section{The composition and physical properties of milk, whey and cheese}

In Table 1 the composition and the quality properties of milk, whey and cheese are presented. Significant differences were observed in the content of solids, protein and lactose in milk. Milk of the RW cows was characterised by the greatest content of solids while the milk of the HO cows had the lowest. The total protein content of the milk of the RP cows was significantly greater than the protein content in the milk of other cows. The milk of RP cows was characterised also by the greatest content of lactose, while the lowest content of this component was characteristic for the milk of HO cows.

The whey remaining after production of cheese from HO, RW and RP milk differed significantly in the content of individual components. However, its acidity was comparable. The greatest content of dry matter and lactose was found in the whey after production of the cheeses from the milk of RP cows and the lowest in the whey 
from the milk of HO cows. The greatest protein content was observed in the whey from the milk of RW cows and the greatest fat content in the whey from the milk of HO cows.

Table 1 . The composition and physical properties of milk, whey and cheese (mean value \pm SD, $n=9$ )

\begin{tabular}{|c|c|c|c|}
\hline \multirow{2}{*}{ Traits } & \multicolumn{3}{|c|}{ Source of milk } \\
\hline & $\mathrm{HO}$ & RW & $\mathrm{RP}$ \\
\hline \multicolumn{4}{|c|}{ Milk } \\
\hline Solids (\%) & $11.11 \pm 0.01 \mathrm{a}$ & $11.65 \pm 0.01 \mathrm{~b}$ & $11.51 \pm 0.01 \mathrm{c}$ \\
\hline Protein $(\%)$ & $3.17 \pm 0.02 \mathrm{a}$ & $3.19 \pm 0.01 \mathrm{a}$ & $3.24 \pm 0.01 \mathrm{~b}$ \\
\hline Fat $(\%)$ & $2.60 \pm 0.20$ & $2.70 \pm 0.10$ & $2.60 \pm 0.10$ \\
\hline Lactose $(\%)$ & $4.67 \pm 0.01 \mathrm{a}$ & $4.73 \pm 0.01 \mathrm{~b}$ & $4.81 \pm 0.01 \mathrm{c}$ \\
\hline Ash (\%) & $0.72 \pm 0.01$ & $0.72 \pm 0.02$ & $0.71 \pm 0.03$ \\
\hline Density $\left(\mathrm{g} / \mathrm{cm}^{3}\right)$ & $1.032 \pm 0.000$ & $1.032 \pm 0.000$ & $1.032 \pm 0.000$ \\
\hline Acidity ( $\left.{ }^{\circ} \mathrm{SH}\right)$ & $6.60 \pm 1.00$ & $6.00 \pm 0.50$ & $7.00 \pm 0.50$ \\
\hline $\mathrm{pH}$ & $6.78 \pm 0.05$ & $6.81 \pm 0.06$ & $6.74 \pm 0.04$ \\
\hline \multicolumn{4}{|c|}{ Whey } \\
\hline Dry matter (\%) & $6.34 \pm 0.01 \mathrm{a}$ & $6.40 \pm 0.01 \mathrm{~b}$ & $6.56 \pm 0.01 \mathrm{c}$ \\
\hline Protein $(\%)$ & $0.98 \pm 0.01 \mathrm{a}$ & $1.13 \pm 0.01 \mathrm{~b}$ & $1.01 \pm 0.01 \mathrm{c}$ \\
\hline Fat $(\%)$ & $0.12 \pm 0.01 \mathrm{a}$ & $0.07 \pm 0.01 \mathrm{~b}$ & $0.08 \pm 0.00 \mathrm{~b}$ \\
\hline Lactose $(\%)$ & $4.57 \pm 0.00 \mathrm{a}$ & $4.66 \pm 0.00 \mathrm{~b}$ & $4.79 \pm 0.00 \mathrm{c}$ \\
\hline Acidity ( $\left.{ }^{\circ} \mathrm{SH}\right)$ & $23.20 \pm 2.80$ & $23.70 \pm 1.70$ & $23.50 \pm 2.70$ \\
\hline \multicolumn{4}{|c|}{ Cheese } \\
\hline Moisture (\%) & $67.56 \pm 1.80$ & $66.46 \pm 1.86$ & $66.74 \pm 3.67$ \\
\hline Protein $(\%)$ & $14.43 \pm 2.24$ & $14.24 \pm 1.14$ & $14.51 \pm 1.55$ \\
\hline Fat ( $\%$ of dry matter) & $41.06 \pm 1.34 \mathrm{a}$ & $46.67 \pm 1.15 \mathrm{~b}$ & $43.45 \pm 2.20 \mathrm{a}, \mathrm{b}$ \\
\hline Acidity $\left({ }^{\circ} \mathrm{SH}\right)$ & $73.00 \pm 6.00$ & $76.00 \pm 5.00$ & $75.00 \pm 6.00$ \\
\hline $\mathrm{pH}$ & $4.50 \pm 0.15$ & $4.52 \pm 0.08$ & $4.53 \pm 0.11$ \\
\hline
\end{tabular}

All cheeses were characterised by a similar composition. Significant differences were stated only in fat content in dry matter of $\mathrm{HO}$ and RW cheeses. A greater content of fat was stated in cheese from the milk of RW cows than in cheese from the milk of HO cows.

\section{The sensory and textural properties of cheese}

In the sensory evaluation of cheeses no significant differences were stated in relation to source of milk except smell (Table 2). The aroma of cheeses produced from the milk of RP cows was rated as better than the aroma of cheeses from the milk 
of HO cows. Differences in overall sensory quality between the cheeses from HO and RW milk compared in the triangle test were detected correctly in 6 cases while between the cheeses from HO and RP milk only in 7 cases. This means that in both cases a significant difference in the organoleptic quality of analysed cheeses was not confirmed.

Table 2 . The sensory $(n=18)$ and textural $(n=9)$ properties of fromage frais-type cheese (mean value $\pm \mathrm{SD})$

\begin{tabular}{l|c|c|c}
\hline \multirow{2}{*}{ Traits } & \multicolumn{3}{c}{ Source of milk } \\
\cline { 2 - 4 } & HO & RW & RP \\
\hline Sensory evaluation (scale 1-5): & & & \\
overall (score) & $4.43 \pm 0.06$ & $4.46 \pm 0.06$ & $4.48 \pm 0.18$ \\
colour (score) & $4.81 \pm 0.17$ & $4.72 \pm 0.35$ & $4.78 \pm 0.25$ \\
appearance (score) & $4.50 \pm 0.08$ & $4.47 \pm 0.13$ & $4.56 \pm 0.39$ \\
consistency (score) & $4.78 \pm 0.31$ & $4.61 \pm 0.17$ & $4.64 \pm 0.34$ \\
taste (score) & $4.11 \pm 0.19$ & $4.31 \pm 0.10$ & $4.28 \pm 0.21$ \\
smell (score) & $4.11 \pm 0.19 \mathrm{a}$ & $4.36 \pm 0.13 \mathrm{a}, \mathrm{b}$ & $4.53 \pm 0.13 \mathrm{~b}$ \\
Texture analysis: & & & $15.66 \pm 1.56 \mathrm{~b}$ \\
hardness (N) & $19.78 \pm 1.59 \mathrm{a}$ & $17.54 \pm 0.97 \mathrm{a}, \mathrm{b}$ & $11.16 \pm 1.21$ \\
adhesiveness (kG×s) & $11.42 \pm 0.65$ & $10.71 \pm 0.11$ & $0.94 \pm 0.01$ \\
springiness (adimensional) & $0.92 \pm 0.03$ & $0.91 \pm 0.03$ & $0.40 \pm 0.09$ \\
cohesiveness (adimensional) & $0.42 \pm 0.05$ & $0.42 \pm 0.03$ & $6.52 \pm 0.32 \mathrm{~b}$ \\
chewiness (N) & $7.65 \pm 0.27 \mathrm{a}$ & $6.80 \pm 0.48 \mathrm{~b}$ & $0.02 \pm 0.01$ \\
resilience (adimensional) & $0.03 \pm 0.00$ & $0.02 \pm 0.01$ & \\
\hline
\end{tabular}

$\mathrm{a}-\mathrm{b}$ - values with different letters within a row are significantly different $(\mathrm{P}<0.05)$.

HO - Polish Holstein-Friesian Black-and-White, RW - Polish Holstein-Friesian Red-and-White, RP - Polish Red.

Although on the basis of organoleptic evaluation of consistency no differences were stated among cheeses, the instrumental texture analysis showed significant differences in hardness and chewiness of the produced cheeses (Table 2). The cheeses from milk of HO cows were harder than cheeses from the milk of RP cows. The chewiness of cheeses from the milk of HO cows was also significantly greater than that of cheeses from the milk of both RW and RP cows.

\section{The protein fractions of cheese}

On the basis of electrophoretic distribution of proteins of the produced cheeses the significant differences in the content of individual protein fractions were stated (Table 3). The greatest content of $\alpha$-casein fraction was stated in cheeses from the milk of HO cows, while the lowest content of this fraction was in cheeses from the milk of RW cows. The content of $\gamma$-casein and $\alpha$-lactoalbumin $(\alpha-\mathrm{La})$ in cheeses from the milk of RW cows was significantly greater than in cheeses from the milk of other cows. The greatest level of $\beta$-lactoglobulin $(\beta-\mathrm{Lg})$ was stated also in cheeses 
from the milk of RW cows and the lowest level of this fraction was in cheeses from the milk of HO cows. However, the level of $\beta$-Lg in RP did not differ from other cheeses. Cheeses from the milk of RP cows contained a significantly greater content of bovine serum albumin (BSA) than in cheeses from the milk of HO and RW cows.

Table 3. The protein fractions of fromage frais-type cheese (mean value $\pm \mathrm{SD}, \mathrm{n}=18$ )

\begin{tabular}{l|c|c|c}
\hline \multirow{2}{*}{\multicolumn{1}{c}{ Protein fractions (\%) }} & \multicolumn{3}{c}{ Source of milk } \\
\cline { 2 - 4 } & HO & RW & RP \\
\hline$\alpha$-casein & $43.98 \pm 1.01 \mathrm{a}$ & $30.58 \pm 0.10 \mathrm{~b}$ & $40.66 \pm 1.71 \mathrm{c}$ \\
$\beta$-casein & $28.37 \pm 1.58$ & $27.79 \pm 4.38$ & $28.18 \pm 0.33$ \\
$\kappa$-casein & $2.72 \pm 0.72$ & $4.01 \pm 0.93$ & $4.64 \pm 1.16$ \\
para -casein & $15.24 \pm 0.24$ & $15.99 \pm 2.87$ & $12.92 \pm 1.32$ \\
$\gamma$-casein & $4.36 \pm 0.76 \mathrm{a}$ & $9.51 \pm 0.05 \mathrm{~b}$ & $4.07 \pm 1.57 \mathrm{a}$ \\
$\alpha$-lactoalbumin & $1.22 \pm 0.23 \mathrm{a}$ & $4.31 \pm 1.62 \mathrm{~b}$ & $1.90 \pm 0.03 \mathrm{a}$ \\
$\beta$-lactoglobulin & $1.99 \pm 1.00 \mathrm{a}$ & $4.74 \pm 1.24 \mathrm{~b}$ & $3.06 \pm 0.63 \mathrm{a}, \mathrm{b}$ \\
lactoferrin & $1.02 \pm 0.16$ & $1.20 \pm 0.01$ & $1.51 \pm 0.52$ \\
bovine serum albumin (BSA) & $1.30 \pm 0.16 \mathrm{a}$ & $1.48 \pm 0.01 \mathrm{a}$ & $2.33 \pm 0.11 \mathrm{~b}$ \\
\hline
\end{tabular}

a-c - values with different leeters within a row are significantly different $(\mathrm{P}<0.05)$.

HO - Polish Holstein-Friesian Black-and-White, RW - Polish Holstein-Friesian Red-and-White, RP - Polish Red.

\section{The profile of fatty acids of cheese}

The composition of fatty acids of fat obtained from examined cheeses is presented in Table 4. The sum of volatile fatty acids of the analysed cheeses did not differ significantly. However, significant differences were stated in the content of individual fatty acids in the group of volatile fatty acids, such as butyric and capric. A greater content of butyric acid and lower content of capric acid was determined in the fat of RW and RP cheeses than in the one from the milk of HO cows.

The greatest content of saturated fatty acids was found in the fat of cheeses from the milk of HO cows. Cheese made of HO milk contained a greater proportion of lauric, myristic and palmitic acids than other cheeses. The greatest content of pentadecylic and arachidic acids was determined in the fat from RW cheese. This cheese also contained more margaric acid than the $\mathrm{HO}$ and RP cheeses. Cheeses made of RW and RP milk were characterised by a greater proportion of stearic acid than $\mathrm{HO}$ cheese.

The sum of MUFA was greater in RW and RP cheeses than in HO one. The amount of myristoleic and eicosenoic acid was greater in RW cheese than in the others. The proportion of margaroleic and oleic acid was greater in RW and RP cheese than in HO one. Cheese made of RP milk contained more palmitoleic acid than other cheeses and the greatest level of trans-vaccenic acid.

PUFA represented a greater proportion of the fatty acids profile in RP cheese than in the others. The content of linoleic acid was determined in larger quantity also in cheeses from the milk of RP cows. Cheeses made of RW and RP milk contained more $\gamma$-linolenic acid than $\mathrm{HO}$ cheese. $\mathrm{HO}$ and RW cheeses were characterised by 
a greater proportion of $\alpha$-linolenic acid than RW cheeses. The fat of analysed cheeses was also significantly diverse regarding the content of cis-9, trans-11 linoleic acid. The cheese from the milk of RW cows exhibited the greatest content of this fatty acid, significantly less was determined in the cheese from the milk of RP cows and the lowest amount of this isomer of CLA was found in the cheese from the milk of HO cows.

Table 4. The profile of fatty acids of fromage frais-type cheese (mean value $\pm S D, n=9$ )

\begin{tabular}{|c|c|c|c|}
\hline \multirow{2}{*}{ Fatty acids (\%) } & \multicolumn{3}{|c|}{ Source of milk } \\
\hline & $\mathrm{HO}$ & RW & $\mathrm{RP}$ \\
\hline \multicolumn{4}{|c|}{ Volatile } \\
\hline Butyric C4:0 & $3.41 \pm 0.07 \mathrm{a}$ & $3.80 \pm 0.07 \mathrm{~b}$ & $3.72 \pm 0.02 \mathrm{~b}$ \\
\hline Caproic C6:0 & $2.69 \pm 0.02$ & $2.73 \pm 0.12$ & $2.70 \pm 0.04$ \\
\hline Caprylic C8:0 & $1.75 \pm 0.01$ & $1.71 \pm 0.08$ & $1.75 \pm 0.03$ \\
\hline Capric C10:0 & $4.11 \pm 0.02 \mathrm{a}$ & $3.63 \pm 0.17 \mathrm{~b}$ & $3.83 \pm 0.11 \mathrm{~b}$ \\
\hline Caproleic C 10:1 & $0.41 \pm 0.01$ & $0.43 \pm 0.02$ & $0.42 \pm 0.02$ \\
\hline Volatile (total) & $12.36 \pm 0.07$ & $12.29 \pm 0.44$ & $12.41 \pm 0.18$ \\
\hline \multicolumn{4}{|c|}{ Saturated } \\
\hline Lauric C12:0 & $4.54 \pm 0.02 \mathrm{a}$ & $3.94 \pm 0.15 \mathrm{~b}$ & $4.16 \pm 0.13 b$ \\
\hline Myristic C14:0 & $13.85 \pm 0.05 \mathrm{a}$ & $13.33 \pm 0.16 \mathrm{~b}$ & $12.69 \pm 0.27 \mathrm{~b}$ \\
\hline Pentadecylic C15:0 & $1.29 \pm 0.00 \mathrm{a}$ & $1.38 \pm 0.02 \mathrm{~b}$ & $1.02 \pm 0.03 \mathrm{c}$ \\
\hline Palmitic C16:0 & $34.56 \pm 0.38 \mathrm{a}$ & $29.76 \pm 0.08 \mathrm{~b}$ & $29.37 \pm 0.49 \mathrm{~b}$ \\
\hline Margaric C17:0 & $0.44 \pm 0.01 \mathrm{a}$ & $0.55 \pm 0.03 \mathrm{~b}$ & $0.46 \pm 0.01 \mathrm{a}$ \\
\hline Tearic C18:0 & $8.55 \pm 0.28 \mathrm{a}$ & $9.75 \pm 0.13 \mathrm{~b}$ & $9.80 \pm 0.32 \mathrm{~b}$ \\
\hline Arachidic C20:0 & $0.14 \pm 0.01 \mathrm{a}$ & $0.15 \pm 0.00 \mathrm{~b}$ & $0.12 \pm 0.01 \mathrm{c}$ \\
\hline Saturated (total) & $63.36 \pm 0.72 \mathrm{c}$ & $58.84 \pm 0.22 \mathrm{a}$ & $57.60 \pm 0.58 \mathrm{~b}$ \\
\hline \multicolumn{4}{|c|}{ Monounsaturated } \\
\hline Myristoleic C14:1 & $1.12 \pm 0.03 \mathrm{a}$ & $1.28 \pm 0.05 \mathrm{~b}$ & $1.17 \pm 0.03 \mathrm{a}$ \\
\hline Palmitoleic C16:1 & $1.91 \pm 0.09 \mathrm{a}$ & $1.91 \pm 0.06 \mathrm{a}$ & $2.07 \pm 0.07 \mathrm{~b}$ \\
\hline Margaroleic C17:1 & $0.23 \pm 0.01 \mathrm{a}$ & $0.32 \pm 0.03 \mathrm{~b}$ & $0.27 \pm 0.02 \mathrm{~b}$ \\
\hline Oleic C18:1n-9 & $16.70 \pm 0.39 \mathrm{a}$ & $20.43 \pm 0.51 \mathrm{~b}$ & $21.20 \pm 0.67 \mathrm{~b}$ \\
\hline Trans-vaccenic C18:1n-7 & $1.85 \pm 0.02 \mathrm{a}$ & $2.37 \pm 0.04 \mathrm{~b}$ & $2.48 \pm 0.04 \mathrm{c}$ \\
\hline Eicosenoic C20:1 & $0.10 \pm 0.00 \mathrm{a}$ & $0.13 \pm 0.02 \mathrm{~b}$ & $0.11 \pm 0.01 \mathrm{a}$ \\
\hline Monounsaturated (total) & $21.91 \pm 0.54 \mathrm{a}$ & $26.42 \pm 0.59 \mathrm{~b}$ & $27.29 \pm 0.64 \mathrm{~b}$ \\
\hline \multicolumn{4}{|c|}{ Polyunsaturated } \\
\hline Linoleic C18:2 n-6 & $1.27 \pm 0.06 \mathrm{a}$ & $1.24 \pm 0.03 \mathrm{a}$ & $1.39 \pm 0.07 \mathrm{~b}$ \\
\hline$\gamma$-linolenic C18:3n-6 & $0.07 \pm 0.01 \mathrm{a}$ & $0.08 \pm 0.00 \mathrm{~b}$ & $0.08 \pm 0.00 \mathrm{~b}$ \\
\hline$\alpha$-linolenic C18:3n-3 & $0.50 \pm 0.05 \mathrm{~b}$ & $0.41 \pm 0.03 \mathrm{a}$ & $0.53 \pm 0.02 \mathrm{~b}$ \\
\hline cis-9,trans-11-linoleic & $0.52 \pm 0.01 \mathrm{a}$ & $0.71 \pm 0.01 \mathrm{~b}$ & $0.66 \pm 0.02 \mathrm{c}$ \\
\hline Polyunsaturated (total) & $2.35 \pm 0.12 \mathrm{a}$ & $2.43 \pm 0.05 \mathrm{a}$ & $2.66 \pm 0.11 \mathrm{~b}$ \\
\hline
\end{tabular}

a-c - values with different letters within a row are significantly different $(\mathrm{P}<0.05)$.

HO - Polish Holstein-Friesian Black-and-White, RW - Polish Holstein-Friesian Red-and-White, RP - Polish Red. 


\section{The cheese yield}

The cheese yield was as follows: $18.8 \mathrm{~kg}$ of cheese was produced from $100 \mathrm{l}$ of milk of RP cows, $17.7 \mathrm{~kg}$ of cheese was obtained from $100 \mathrm{l}$ of milk of RW cows and $16.6 \mathrm{~kg}$ of cheese was manufactured from 1001 of milk of HO cows. The greatest cheese yield was obtained from the milk of RP cows and the lowest from the milk of HO cows $(\mathrm{P}<0.05)$.

\section{Discussion}

\section{The composition and physical properties of milk, whey and cheese}

Litwińczuk et al. (2012) studied the basic composition of milk of different cow breeds (White-backed, RP, Polish Black-and-White, HO and Simmental) and they found the content of protein in milk of RP and HO cows at the level of 3.61\% and $3.49 \%$, respectively. The results obtained in our work are slightly lower than the aforementioned levels. However, it should be noted that in our studies the milk was standardised to fat content of $2.6 \% \pm 0.1 \%$, hence the solids content of the milk was smaller than given in the literature for non-standardised milk. Normalisation of fat content can cause a small decrease in protein content as the fat globules are covered by a membrane which contains mostly protein and phospholipids (Lu et al., 2016). Nevertheless, the content of lactose as well as the acidity of milk determined in our work were similar to the results described by Litwińczuk et al. (2012). Litwińczuk et al. (2014) also examined the chemical composition of milk from HO and RW cows. They determined no significant difference in levels of protein $(3.44 \%$ and $3.40 \%)$ and lactose content (4.75\% and $4.73 \%$ ) between $\mathrm{HO}$ and RW milk. In the presented work we also determined a similar amount of protein in $\mathrm{HO}$ and RW milk, however, slightly lower than in the studies conducted by Litwińczuk et al. (2014). Król et al. (2011) reported similar $\mathrm{pH}$ levels to ours: $\mathrm{pH}$ for the milk of HO and RW cows was 6.70 and 6.68 , respectively.

The greatest content of solids and lactose was found in whey after production of cheeses from milk of RP cows and the lowest in whey from milk of HO cows. This was probably due to similar dependence of the content of solids and lactose in RP and HO milk. The greatest protein content was observed in whey from milk of RW cows and the greatest fat content in whey from milk of $\mathrm{HO}$ cows. The transfer of the greater quantities of protein and fat to whey can cause smaller yield of cheese production.

The obtained results of basic chemical composition of fromage frais-type cheeses were similar to those reported by Ningtyas et al. (2017) for high-fat cream cheese produced by acid-rennet coagulation which is a similar kind of cheese. A greater content of fat in dry matter was stated in cheese from the milk of RW cows than in the one of HO cows. This agrees with the fat content in whey, which was greater in $\mathrm{HO}$ than in RW.

\section{The sensory and textural properties of cheese}

Hurtaud et al. (2009) reported the significant influence of cow breed on sensory assessed texture and taste of Camembert. Moreover, Pizzillo et al. (2005) concluded 
that goat breed affects the texture and smell of ricotta. On the other hand, Soryal et al. (2005) examined soft cheeses produced by acid-rennet coagulation of goat milk and stated that there was no significant influence of animal breed on cheese sensory assessment. Our results are partially consistent with the studies of Pizzillo et al. (2005) as the fromage frais-type cheeses differed in smell.

De Marchi et al. (2008), who investigated the influence of cow breed (Holstein Friesian and Brown Swiss) on the quality of Casolet, Vezzena and Grana Trentino cheeses, concluded that regardless of the type of cheese there was no significant influence of cow breed on texture assessed instrumentally. These results are not in agreement with our studies as the fromage frais-type cheeses differed in hardness and chewiness.

\section{The protein fractions of cheese}

Litwińczuk et al. (2011) determined the content of individual fractions of whey proteins in milk of HO and RW cows using the HPLC method. They found no significant influence of cow breed on the content of a-La and BSA. However, the amount of $\beta-\mathrm{Lg}$ was greater in $\mathrm{HO}$ milk and lactoferrin was greater in RW one. On the other hand, Król et al. (2011) also determined the content of selected whey proteins in milk of the same cow breeds and they observed a greater amount of $\beta$-Lg and BSA in the milk of RW than HO. At the same time, there was no significant influence of breed on the content of $\alpha$-La and lactoferrin. These results are partially consistent with our work. However, they were obtained after analysis of milk while in our study acidrennet curd cheese was examined. To our knowledge, there are no results of protein fractions determined in cheeses made from milk of different cow breeds.

According to Litwińczuk et al. (2012) milk of RP cows compared to the milk of Polish Holstein-Friesian (unknown type) contains more $\alpha$-La, $\beta$-Lg, lactoferrin and BSA. However, in this research, the RP breed was maintained in a traditional system, whereas the other one - in an intensive one. Therefore, the difference could have been due to the feeding. In our research, only the amount of BSA was greater in the cheese made from the RP milk than in the others.

According to Król et al. (2011) and Litwińczuk et al. (2011, 2012), $\beta$-Lg was the dominant whey protein in the milk of HO, RW and RP cows. This was also observed in the investigated fromage frais-type cheeses.

\section{The profile of fatty acids of cheese}

The profile of fatty acids in cheese is strongly affected by their composition in the milk, whereas the cheese-making technology has a relatively small influence (De Marchi et al., 2008). Therefore, the profile of fatty acids determined in the fromage frais-type cheeses can be compared with the profile of fatty acids in the milk of HO, RW and RP cows.

The contents of MUFA and PUFA determined in the fat of cheese from the milk of HO and RW cows were comparable to the values stated by Litwińczuk et al. (2014, 2016) in the fat of the milk from these cows, whereas the level of cis-9, trans-11 linoleic acid was greater in our results. However, in the above-mentioned research, the $\mathrm{HO}$ and RW cows were maintained in the intensive system and fed with TMR which 
could have caused the decrease in the CLA content in milk. Nevertheless, HO and RW cows raised on the same type of feeding gave milk which differed in the MUFA, PUFA and CLA contents. Their levels were significantly greater in the RW than in the HO milk (Litwińczuk et al., 2014). The same relationship was observed between the analysed HO and RW cheeses regarding MUFA and CLA.

Moreover, according to Król et al. (2015) and Litwińczuk et al. (2016) the average contents of MUFA, PUFA and CLA in milk of RP breed are 27.76 and $27.69 \%$, 3.86 and $3.82 \%, 0.78$ and $0.76 \%$, respectively. Thus, our results are comparable. Moreover, Litwińczuk et al. (2016) stated that the contents of MUFA, PUFA and CLA are greater in the milk of RP than HO cows. These results are in agreement with our findings regarding the fatty acids of fromage frais-type cheeses.

Significant variation in CLA content in milk from cows raised on different type of feeding could have been expected. There are several factors that influence the fatty acid profile in cow's milk, i.e. CLA content. For instance, type and quantity of pasture consumed, dietary restrictions, oil supplements incorporated into diet, amount and type of ration, the production system, breed and age of animals can affect the content of individual fatty acids. Moreover, the season in which milk is collected may involve reduced accessibility of pastures rich in PUFA. A number of studies have indicated that depending on availability of pastures and fat supplemented rations (primarily soybean and rapeseed or its oil), the CLA content in milk can be increased significantly even by 50\% (Stanton et al., 1997).

In general, the content of individual fatty acids was comparable to the ranges of occurrence of these acids in bovine milk fat described by Moate et al. (2007). Significant diferences in the amount of individual fatty acids between cheeses made from the milk of different cattle breeds were also determined by De Marchi et al. (2008). They concluded that cow breed (Holstein Friesian and Brown Swiss) influences the composition of most fatty acids present in fat of Casolet and Grana Trentino cheeses. However, in Vezzena cheese, significant effect was stated only in the amount of lauric and $\alpha$-linolenic acid. The same conclusion was stated by Pizzillo et al. (2005) regarding ricotta cheese made from milk of four goat breeds. However, Soryal et al. (2005) concluded that there was no significant effect of goat breed (Alpine and Nubian) on the composition of fatty acids in soft cheese, except oleic acid and the sum of unsaturated fatty acids. Our results are closer to the findings of De Marchi et al. (2008) and Pizzillo et al. (2005).

\section{The cheese yield}

The results of cheese yield are in agreement with the conclusions of De Marchi et al. (2008) and Auldist et al. (2004) considering the effect of cow breed on cheese yield. Moreover, Soryal et al. (2005) concluded that also the goat breed affects cheese yield of soft cheese.

\section{Conclusions}

The obtained results indicate that cow breed or type influences content of total solids, protein and lactose in milk standardised to fat level. Moreover, the amount of total solids, protein, fat and lactose in whey obtained after fromage frais-type cheese 
production also varies according to cow breed or type. However, cheeses produced from $\mathrm{HO}$, RW and RP milk do not differ significantly in acidity and chemical composition - there was a significant difference only in fat in dry matter content. The results indicate that the cow breed or type has a minor effect on sensory properties of fromage frais-type cheese, as it has an influence only on their smell. However, texture analysis shows that there is a significant difference in hardness and chewiness between cheeses. The differences determined between cheeses made from HO and RP milk, as well as from RW and RP milk could have been caused not only by the cow breed or type but also by feeding. Nevertheless, a comparison of the nutritional value of $\mathrm{HO}$ and RW cheeses shows that the RW milk is a more beneficial raw material for fromage frais-type cheese. The cheese prepared from the milk of RW cows was characterised by a greater proportion of $\alpha$-La, $\beta-\mathrm{Lg}$, trans-vaccenic acid, cis-9,trans-11-linoleic acid and MUFA and a lower amount of SFA than the cheese made from the HO milk. However, taking into account the yield of cheese, the best raw material is the RP breed milk.

\section{References}

A d a m c z y k K., S z a r e k J. (2009). Polish Red Cattle - "lesson" for the future (in Polish). Prz. Hod., 8: 9-12.

A u 1 d is t M.J., J oh nst on K.A., Wh it e N.J., F i tz si mon s W.P., B o 1 and M.J. (2004). A comparison of the composition, coagulation characteristics and cheesemaking capacity of milk from Friesian and Jersey dairy cows. J. Dairy Res., 71: 51-57.

B arłowska J., Litwińczuk Z., Wol anciuk A., Pastuszka R. (2014). The chemical composition, cytological quality and technological suitability of the milk of three breeds of red and white cows fed in a TMR system. Sci. Ann. Polish Soc. Anim. Prod., 10: 115-124.

B aryłko-Pikielna N., M at us zew sk a I. (2014). Sensory analysis of food. Basics - MethodsApplications (in Polish). Kraków, Poland, Wydawnictwo Naukowe PTTŻ, pp. 134-138, 163-169, 355 .

CODEX STAN 275-1973 (last amendment in 2016). Standard for cream cheese. Rome, Italy, FAO/ WHO Codex Alimentarius Commision.

d e M a n J.M. (1964). Determination of fatty acid composition of milk fat by dual column temperature programmed gas liquid chromatography. J. Dairy Sci., 47: 546-547.

De Marchi M., Bittante G., Dal Zotto R., Dalvit C., Cassandro M. (2008). Effect of Holstein Friesian and Brown Swiss breeds on quality of milk and cheese. J. Dairy Sci., 91: $4092-4102$.

Domagała J., Pluta-Kubica A., Pustkowiak H. (2013). Changes in conjugated linoleic acid content in emmental-type cheese during manufacturing. Czech J. Food Sci., 31: 432-437.

F o l ch J., Le e s M., S l o a n e-S t an ley G.H. (1957). A simple method for the isolation and purification of total lipids from animal tissues. J. Biol. Chem., 226: 497-509.

Horwitz W., Latimer G. (2007). Editors. Official methods of analysis of AOAC International. Arlington, VA, USA, AOAC International, 18th ed.

http://pfhb.pl/fileadmin/user_upload/OCENA/publikacje/publikacje_2019/RO_Parzniew-wyniki_oceny_za_rok_2018.pdf) (online 26.07.2019)

Hurtaud C., Peyraud J.L., Michel G., B er the lot D., De laby L. (2009). Winter feeding systems and dairy cow breed have an impact on milk composition and flavour of two Protected Designation of Origin French cheeses. Animal, 3: 1327-1338.

ISO 3433:2008. Cheese - Determination of fat content - Van Gulik method. Geneva, Switzerland, International Organization for Standardization. 
Król J., Brodziak A., Litwińczuk A. (2011). Basic chemical composition and content of selected whey proteins in milk from different cow breeds and in rennet whey (in Polish). Zywn. Nauk. Technol. Ja., 18: 74-83.

Król J., Litwiń c zuk Z., Matwijczuk A. (2015). Fatty acid profile and cholesterol content of the milk of cows raised in a low-input system, taking into account the production season (in Polish). Rocz. Nauk. Zoot., 11: 95-102.

L a e m m l i U.K. (1970). Cleavage of structural proteins during the assembly of the head of bacteriophage T4. Nature, 227: 680-685.

Litwińczuk Z., Król J., Brodziak A., B arłowska J. (2011). Changes of protein content and its fractions in bovine milk from different breeds subject to somatic cell count. J. Dairy Sci., 94: 684-691.

Litwińczuk Z., Barłowska J., Chabuz W., Brodziak A. (2012). Nutritional value and technological suitability of milk from cows of three polish breeds included in the genetic resources conservation programme. Ann. Anim. Sci., 12: 423-432.

Litw iń c zuk Z., K ow a 1 M., B a rłow s ka J. (2014). Basic chemical composition, proportion of fatty acids, and cholesterol content in milk of four breeds of cows used in the intensive husbandry technologies (in Polish). Zywn. Nauk. Technol. Ja., 21: 108-121.

Litwińczuk Z., M a tw i j c zuk A., B rodziak A. (2015). Food energy, physical properties, and processing suitability of milk from cows of Polish Red Whitebacked and Simmental breeds kept using low-input system (in Polish). Zywn. Nauk. Technol. Jakosc, 6: 106-117.

Litwińczuk Z., B arłowska J., Matwijczuk A., Slomiany J. (2016). Changes in milk yield and quality during lactation in Polish Red and White-Backed cows included in the genetic resources conservation programme in comparison with the Simmental breed. Ann. Anim. Sci., 16: $871-886$.

Lu J., Argov-Argaman N., Anggrek J., Boeren S., van Hooijdonk T., Vervoort J., Hetting a K. A. (2016). The protein and lipid composition of the membrane of milk fat globules depends on their size. J. Dairy Sci., 99: 4726-4738.

Manual of the Universal Texture Analyser TA-XTPlus.

Moate P.J., Chalupa W., B oston R.C., L e a n I.J. (2007). Milk fatty acids. I. Variation in the concentration of individual fatty acids in bovine milk. J. Dairy Sci., 90: 4730-4739.

Ningtyas D.W., Bhandari B., Bansal N., Prakash S. (2017). A tribological analysis of cream cheeses manufactured with different fat content. Int. Dairy J., 73: 155-165.

Pizzillo M., Claps S., C ifuni G.F., F edele V., Rubino R. (2005). Effect of goat breed on the sensory, chemical and nutritional characteristics of ricotta cheese. Livest. Prod. Sci., 94: 33-40.

S oryal K., B e ye ne F.A., Z eng S., B ah B., Te s fai K. (2005). Effect of goat breed and milk composition on yield, sensory quality, fatty acid concentration of soft cheese during lactation. Small Rumin. Res., 58: 275-281.

Stanton C., Law less F., Kjellmer G., Harrington D., D every R., Connolly J.F., Murph y J. (1997). Dietary influences on bovine milk cis-9,trans-11-conjugated linoleic acid content. J. Food Sci., 62: 1083-1086.

Received: 29 III 2019

Accepted: 13 XI 2019 